\title{
SOCIAL SKILL TRAINING (SST) SEBAGAI INTERVENSI PADA ANAK DENGAN GANGGUAN SIKAP MENENTANG
}

\author{
Ni Gusti Made Rai
}

\begin{abstract}
Abstrak
Perubahan jaman menunjukkan adanya berbagai macam problem sosial yang salah satunya sering terjadi di masyarakat adalah anak yang suka membuat masalah atau bullying. Dalam bahasa awam lebih dikenal oleh masyarakat yaitu dengan istilah anak membangkang, dan dalam bahasa ilmiah disebut dengan Oppositional Deviant Disorder (ODD). Strategi untuk mengatasi persoalan tersebut, yang mampu mengurangi persoalan ODD adalah lingkungan bukan hanya para ahli Psikolog saja. Diharapkan ada gerakan yang mampu menumbuhkan adanya kemampuan sosial (social skill) yakni dengan latihan-latihan yang dapat diprogram oleh para ahli seperti psikolog ataupun psikiater. Oleh karena itu diharapkan Masyarakat mulai mengenal, mengetahui ciri-ciri klinis dari ODD, sehingga mampu menangani persoalan gangguan sikap menentang ini.
\end{abstract}

Kata Kunci : Sosial Skill, ODD

Berdasarkan data yang ada melalui media massa munculnya kasus-kasus kenakalan pada siswa baik yang terjadi di lingkungan sekolah maupun di lainnya. Munculnya keluhan dari orang tua, guru dan lingkungan dalam mengatasi persoalan kenakalan anak. Hal demikian menunjukkan perlunya pengetahuan dalam mengatasi adanya kenakalan yang dapat dikatakan sebagai bentuk perilaku menentang. Jika sejak dini terdapat progam atau cara untuk mengatasinya maka persoalan yang lebih besar dapat dihindari.

Munculnya kasus-kasus kekerasan yang disekolah ataupun perguruan tinggi juga mencerminkan adanya perpanjangan persoalan dari kenakalan anak melalui sikap menentang ataupun memberontak. Hal demikian dapat secara spesifik dirasakan dari adanya kegiatan orientasi siswa ataupun mahasiswa yang justru dijadikan ajang melakukan bullying dan termasuk kekerasan. Kekerasan yang muncul tidak hanya kekerasan fisik.

Pelaku yang dikatakan sebagai subyek dengan kenakalanya menunjukkan adanya persoalan perilaku dan psikologis yang belum terselesaikan. Salah satu masalah exsternal behavior diantaranya yaitu $O D D$. Anak dengan $O D D$ sering kali dianggap menjadi masalah sepele dalam kehidupan sehari, padahal berawal dari 
adanya perilaku sikap menentang di usia kanak-kanak ini akan dapat mengakibatkan perkembangan perilaku anti sosial dan gangguan tingkah laku pada usia selanjutnya (Loeber, dkk., dalam Nevid 2005).

Anak-anak dengan $O D D$ biasanya menunjukkan perilaku negatif dan seperti keras kepala dan melawan pengarahan orang lain. Mereka tidak menginginkan adanya kompromi, memberi atau tidak mau melakukan negosiasi. Anak-anak ini juga biasanya mengabaikan aturan, senang mendebat. Sikap permusuhan ini diarahkan pada orang dewasa atau teman sebaya yang ditunjukkan dengan agresi verbal atau secara sengaja membuat jengkel orang lain (DSM IV, 2000). Anak dengan kondisi demikian tentunya akan mengalami kesulitan berinteraksi di masyarakat baik dengan orang dewasa maupun dengan teman sebayanya, bahkan akan sering muncul konflik diantara mereka (Sumiati, 2006).

Anak dengan gangguan sikap menentang/ODD tersebut memiliki keterbatasan dalam pengetahuannya terhadap keterampilan sosial (social skill acquisition deficits), kesulitan mengkomunikasikan/mengeluarkan perasaannya serta kebutuhannya (social performance deficits), sehingga interaksi yang nampak menjadi sulit dan kurang dapat diterima lingkungan, serta adanya kesulitan dalam pemecahan masalah, sehingga akan nampak ketika anak tersebut harus memutuskan situasi mana untuk memunculkan perilaku yang tepat (Hersen, 2006).

Tujuan dengan diberikannya intervensi dalam bentuk SST adalah untuk mengurangi tingkat gangguan yang ada. Sehingga bagi anak $O D D$ dengan karakteristik diatas melalui teknik dalam SST tentunya akan memiliki perilaku yang lebih prososial. Banyak kalangan menduga bahwa adanya gangguan sikap menentang sebagai sesuatu yang jauh dari sekitar. Jusru gangguan sikap menenatang ini merupakan kasus yang cukup sering kita temui sehari-hari. Dengan tidak diketahuinya cara penanganan yang tepat akan menimbulkan adanya kesulitankesulitan penanganan masalah perilaku yang dapat muncul semakin sulit seiring bertambahnya waktu. 


\section{Definisi Oppositional Deviant Disorder (ODD)}

Menurut DSM IV, gangguan sikap menentang merupakan suatu pola negatif, bermusuhan, tidak patuh dan bentuk perilaku yang menyimpang pada seorang anak atau remaja yang terjadi sekurang-kurangnya selama 6 bulan tanpa melakukan kerasan yang berakibat serius pada hak-hak dasar orang lain. Sikap menentang dikenal dengan sebutan negativism dan anak yang tidak patuh dan tidak mau menuruti perintah atau memenuhi orang yang lebih tua (DSM IV TR, 2000).

Anak-anak dengan gangguan sikap menentang atau Oppositional Deviant Disorder ini biasanya menunjukkan perilaku negatif dan menyimpang seperti keras kepala dan melawan pengarahan orang lain. Mereka tidak menginginkan adanya kompromi, memberi atau tidak mau melakukan negosiasi. Dan anak-anak ini juga biasanya mengabaikan aturan, senang mendebat atau mengabaikan kesalahan atas perilaku yang dibuatnya. Sikap permusuhan ini diarahkan ada orang dewasa atau teman sebaya yang ditunjukkan dengan agresi verbal atau secara sengaja membuat jengkel orang lain (Sumiati, 2006).

\section{Ciri-ciri anak dengan ODD}

Anak-anak dengan gangguan sikap menentang atau Oppositional Deviant Disorder (ODD) ini biasanya menunjukkan perilaku negatif dan menyimpang seperti keras kepala dan melawan arah-arahan orang lain. Mereka tidak menginginkan adanya kompromi, memberi atau tidak mau melakukan negosiasi. Dan anak-anak ini juga biasanya mengabaikan aturan, senang mendebat atau mengabaikan kesalahan atas perilaku yang dibuatnya. Sikap permusuhan ini diarahkan ada orang dewasa atau teman sebaya yang ditunjukkan dengan agresi verbal atau secara sengaja membuat jengkel orang lain (Sumiati, 2006:46).

Menurut Wenar (1994:136), pada gangguan ODD sering kali terjadi keadaan tumpah tindih dengan gangguan perilaku lain yang saling beriringan dengan gejala psikologis lain, terutama agresivitas maupun antisosial dan conduct disorder. ODD memiliki beberapa karakteristik yang mencolok dibandingkan dengan conduct disorder menurut Sachchar dan Wachmuth (Wenar, 1994:136).

Berdasarkan DSM dan PPDGJ III, gangguan perilaku ini menyebabkan berbagai masalah yang signifikan secara klinis didalam lingkungan sosial. Anak- 
anak ini seringkali mengalami pertengkaran dan konflik dengan orang tua, guru, dan teman sebayanya (Sumiati, 2006:46).

Anak dengan ODD berarti memiliki permasalahan dengan social skill (kendal, 2003 dalam Hersen 2006:288), permasalahan tersebut akan dibedakan antara permasalahan kemunduran kognitif dan distorsi kognitif yang ada. Bahkan seringkali dalam penelitian mengenai sikap menentang ini tumpang tindih dengan istilah anak dengan permasalahan sosial atau social impairmentt (Hersen, 2006:286). Kemampuan yang diharapkan bagi anak dengan sikap menentang adalah memiliki toleransi, adaptasi dan kemampuan pemecahan masalah (Greene \& Ablon, 2005 Greence \& Doyle, 1999, dalam Hersen, 2006:287). Karena kemampuan yang berhubungan dengan kapasitas anak dalam menjalin hubungan dalam suatu perubahan lingkungan atau memiliki standar dalam diri mereka mengenai perilaku yang tepat (Hersen, 2006:287). Adanya kemampuan yang berkurang dalam kapasitasnya untuk merespon orang dewasa secara adaptif dan dengan kesopanan (Greene \& Ablon dalam Hersen, 2006:287). Hal ini disebabkan karena mereka merasa hanya perlu merespon secara dengan reaksi emosional tanpa adanya pemahaman atas konsekuensi perilaku yang salah.

Anak dengan ODD memiliki kegagalan dalam melakukan kategori strategi perilaku, dan kekuatan dalam merespon secara verbal yaang seharusnya diarahkan pada ketepatan dalam perilaku selanjutnya. Mereka memiliki label emosi tertentu sehingga adanya rasa frustasi yang membuatnya kesulitan dalam mengidentifikasi secara tepat dalam strategi perilaku yang seharusnya dimunculkan. Anak memiliki keterbatasan dalam mengkomunikasikan perasaannya dan kebutuhannya sehingga interaksi yang nampak menjadi sulit, serta adanya kesulitan dalam pemecahan masalah, sehingga akan nampak ketika anak tersebut harus memutuskan situasi mana untuk memunculkan perilaku yang tepat (Hersen, 2006:287).

\section{Faktor-faktor Penyebab ODD}

Gangguan perilaku ODD merupakan gangguan yang bersifat kompleks dan dipengaruhi oleh beberapa faktor yang saling berinteraksi, yaitu:

\section{a. Faktor Biologis}


Kondisi biologis individu dapat mempengaruhi kerentanan anak untuk mengalami gangguan perilaku. Kondisi biologis ini termasuk tempramen awal, pengaruh genetik, dan faktor neurobilogi. Ketiga hal ini saling terkait yang termasuk faktor biologis yang merupakan indikator paling awal masalah perilaku (Mash\&Wolfe, 1999:211). Tempramen awal anak yang sulit ini meliputi adanya impulsivitas, emosi yang labil, kesulitan dalam memecahkan masalah, sikap malas, negativistik, dan sensitif terhadap situasi stress merupakan beberapa indikator anak yang mengalami ODD (Mash\& wolfe, 1999:211). Tempramen anak jika berinteraksi dengan gaya manajemen atau pengasuhan orang tua yang tidak sesuai maka akan memperparah gangguan ODD yang dialami anak (Grainger, 2003:56, dalam Khosiana, 2008:25). Tempramen awal ini dapat dihasilkan atas interaksi dari pengaruh genetik dan faktor neurobiologis yang ada pada individu yang bersangkutan.

Pengaruh genetik menjelaskan bahwa perilaku agresif dan antisosial ternyata dapat diturunkan oleh keluarga yang memiliki kondisi demikian. Meskipun perilaku antisosial tidak secara langsung dapat diturunkan, namun jika keluarga memiliki kondisi tersebut maka anak memiliki faktor resiko yang lebih tinggi untuk memiliki perilaku yang sama (Mash\& wolfe, 1999:211).

Perilaku yang ditampilkan oleh individu sangat terkait dengan proses interaksi pada sistem saraf di dalam tubuh manusia. Ketika terjadi suatu hambatan atau bahkan sebaliknya adanya hal yang berlebihan dalam proses kerja pada sistem syaraf menjadikan perilaku yang muncul dalam aktivitas sehari-hari menjadi kurang tepat. Misal, seorang anak yang memunculkan perilaku agresif karena adanya hambatan dalam proses pembatasan (kontrol) yang seharusnya terjadi (Mash\& wolfe, 1999:214).

\section{b. Faktor Keluarga}

Menurut Wenar pada salah satu penelitian mengenai hubungan antar pribadi disebutkan bahwa terjadinya ODD pada umumnya dipengaruhi oleh pola relasi orang tua dan anak. Gambaran karakteristik global relasi orang tua dan anak biasanya tidak baik (Wenar, 1994:138). Teori attachment menunjukkan adanya 
masalah kualitas kelekatan anak dengan orang tua pada masa awal kehidupan akan dapat menimbulkan masalah perilaku (misal, antisosial). Karena pada masa awal kehidupan ini adanya kualitas kelekatan yang baik akan mempengaruhi nilai, kepercayaan, dan standar yang dijadikan dasar dalam perilaku yang dipilih anak dalam kehidupan selanjutnya (Mash\& wolfe, 1999:217). Bahkan umumnya anak dengan masalah kelekatan insecure attachment disebutkan dapat mengakibatkan terjadi ODD terutama pada anak laki-laki (Mash\& wolfe, 1999:219). .

Selain itu Mash \& Wolfe menyebutkan bahwa terdapat dua macam disfungsi keluarga yang mempengaruhi: pertama, gangguan spesifik diantaranya meliputi gangguan dalam praktek pengasuhan dan fungsi keluarga misalnya penggunaan pola disiplin yang sangat kasar dan berlebihan, kurangnya pengawasan, kurangnya dukungan emosional dan perselisihan kedua orang tua akan bentuk displin. Kedua, gangguan umum diantaranya meliputi kekacauan keluarga secara umum, seperti adanya psikopatologi dalam keluarga, nilai-nilai anti sosial dalam keluarga sejarah perilaku anti sosial keluarga, ketidakstabilan keluarga dan terbatasnya sumber daya.

Selain itu bahwa suatu proses sosialisasi yaitu transfer nilai dan norma dari orang tua kepada anak juga mempengaruhi secara langsung pada perilaku anak. Tujuan pertama dari proses sosialisasi adalah menumbuhkan self regulasi yaitu kemampuan mengatur perilakunya sendiri tanpa diingatkan dan diawasi orang tua. Self regulasi yang baik maka anak diharapkan mengetahui dan memahami perilaku seperti apa yang dapat diterima orang tua dan lingkungannya (Dohn, Dunn, \& Jones, 2004:59).

\section{c. Faktor Lingkungan}

Lingkungan di luar keluarga yang utama berperan bagi perkembangan perilaku anak adalah teman sebaya, lingkungan masyarakat. Anak-anak yang ditolak memiliki kualitas hubungan yang rendah dengan teman sebaya cenderung menjadikan agresif sebagai strategi dalam berinteraksi (Dohn, Dunn, \& Jones, 2004:63). 


\section{Pengaruh ODD terhadap Lingkungan}

\section{Terhadap Keluarga}

Menurut Biederman, perilaku yang berhubungan dengan ODD menunjukkan adanya pengaruh terhadap interaksi orang tua dan anak. Interaksi orang tua dan anak tersebut menunjukkan adanya ketidakrespekan terhadap orang tua hal ini juga ditemukan pada CD (Hersen, 2006:290). ODD juga banyak terkait dengan gangguan seperti ADHD, dimana mereka juga menunjukkan adanya kesulitan interaksi dengan pengasuh yang ada. Bahkan dalam suatu penelitian disebutkan bahwa ODD merupakan satu-satunya indikasi dari adanya konflik dalam suatu keluarga (Hersen, 2006:290).

\section{Terhadap Sekolah}

Selain itu anak ODD biasanya juga menunjukkan masalah interaksi dengan orang dewasa di sekolah. ODD menjadi signifikan prediktor untuk menemukan problem sekolah (Biederman, dkk 2002 dalam Hersen, 2006:290).

\section{Terhadap Teman}

Anak dengan ODD juga mengalami kesulitan dalam berinteraksi dengan teman sebaya. Salah satu penelitian menemukan bahwa anak dengan ODD memiliki hubungan yang kurang baik dan tidak ada bedanya dengan anak dengan conduct disorder. ODD juga menjadi salah satu signifikan prediktor dari adanya masalah dengan anak lain, sama halnya dengan conduct disorder (Greence, Biederman, dkk 2002 dalam Hersen, 2006:290).

Secara spesifik Oppositinal Deviant Disorder (ODD) dalam penelitian ini adalah suatu perilaku negatif meliputi perilaku mudah marah, melawan arahan atau aturan orang dewasa, tidak adanya kompromi atau negosiasi, perilaku berdebat, agresi secara verbal dan nonverbal untuk membuat orang lain termasuk teman sebaya jengkel yang termasuk bullying, menyalahkan orang lain atas kesalahan diri. 


\section{Definisi Social Skill}

Social skill merupakan kemampuan individu yang berbeda pada masingmasing orang yang akan menimbulkan akibat ketika berinteraksi dengan orang lain yang akhirnya sebagai bentuk suatu kesejahteraan sosial individu. Social skill diartikan sebagai kemampuan untuk berinteraksi baik berupa perilaku positif maupun negatif dan perilaku tersebut akan mendapat reinforment ataupun punisment dari pihak lain (Libet \& Lewinsohn, 1973 dalam Segrin, 2007:638). Menurut Hersen \& Bellack, social skill merupakan kemampuan untuk mengekspresikan perasaan positif dan negatif dalam hubungan interpersonal yang akan mengakibatkan suatu konsekuensi sosial yang positif, dan sebaliknya ketika inidvidu memiliki social skill yang rendah akan menghasilkan suatu konsekuensi sosial yang negatif (Segrin, 2007:638).

Selain itu Walker, 1995 menjelaskan bahwa social skill merupakan suatu kemampuan atau kompetensi individu yang penting dalam menjalin hubungan positif terhadap lingkungan (Chen, 2006:143). Sehingga ketika social skill yang dimiliki buruk akan mengakibatkan kesulitan dalam menjalin hubungan dengan teman sebaya, keluarga, guru dan juga akan berhubungan dengan suatu keadaan psikopatologis tertentu seperti depresi (Segrin, 2007), gangguan perilaku (Gaffney \& McFall; Spence,1981), fobia sosial (Spence, Donovan, \& BrechmanToussaint,1999), dsb sehingga suatu kemampuan social skill ini dibutuhkan sebagai suatu intervensi dan prevensi untuk mencegah terjadi suatu permasalahan kesehalan mental (dalam Spence, 2003:84). Sedangkan Hanley-Maxwell, 2003 menjelaskan bahwa social skill merupakan suatu kemampuan kritis dalam menjalin hubungan, beradaptasi, dan berfungsi dalam suatu lingkungan (Chen, 2006:143). Chen menambahkan bahwa kemampuan berinteraksi yang sukses dengan orang lain akan menambah kekayaan pengalaman hidup, seperti menjalin pertemanan, berhubungan dengan aktivitas menyenangkan, atau terlibat dalam kelompok tertentu. Jadi dengan ketrampilan sosial individu akan memberikan kontribusi yang positif sebagai suatu bagian dari lingkungan sosial tertentu (Chen, 2006:143).

Dapat disimpulkan bahwa kemampuan keterampilan sosial merupakan suatu perlhal yang sangat penting dimiliki seorang individu dalam menjalin interaksi 
sosial. Ketika keterampilan sosial yang dimiliki seorang pada taraf positif maka akan menghasilkan suatu interaksi sosial yang positif. Terdapat suatu pola hubungan yang berbanding lurus antara keterampilan sosial dengan interaksi sosial yang dimiliki seseorang. Anak dengan ODD cenderung memiliki masalah interaksi sosial dan cenderung memiliki ketrampilan sosial yang rendah (Hersen, 2006:288), sehingga perlu adanya model pembelajaran sebagai bentuk penanganan agar menghasilkan keterampilan sosial yang lebih baik. Dengan demikian perilaku yang menjadi karakteristik pada anak dengan ODD akan menurun.

\section{Social Skill Training (SST)}

Sosial Skill Training (SST) atau latihan keterampilan sosial merupakan intervensi dengan menggunakan pendekatan khusus yang bertujuan untuk mengembangkan peningkatan suatu perilaku prososial. Individu diajak untuk mengembangkan ketrampilan alternatif yang tepat dalam mengintepretasi sinyal sosial dan menghasilkan strategi yang tepat terhadap suatu perilaku baru dan lebih adaptif dengan lingkungan sosial. Selain itu SST juga merupakan suatu intervensi yang memiliki peran secara tidak langsung untuk menurunkan perilaku agresif (Jones, 2004). Adanya perilaku yang tidak tepat muncul sebagai respon dari keterbatasan keterampilan yang tidak tepat pada saat berinteraksi dengan orang lain. Pendekatan SST menekankan dengan memberikan pengenalan pada anak pada suatu ketrampilan baru yang dapat diterapkan untuk menghasilkan suatu perilaku dan akhirnya akan menghasilkan suatu repon positif dari orang lain serta sekaligus dapat meningkatan self-esteem yang positif, peningkatan hubungan relasi teman sebaya yang lebih positif yang secara sosial lebih diterima, dan mengurangi penggunaan perilaku yang kurang diterima oleh lingkungan sosial (Jones, 2004).

Jadi dapat disimpulkan bahwa Social skill training (SST) merupakan suatu intervensi yang tepat digunakan untuk meningkatkan keterampilan sosial individu. Artinya peningkatan perilaku prososial dan secara tidak langsung dapat menurunkan tingkat agresi pada anak dengan masalah perilaku termasuk gangguan sikap menentang atau $O D D$. Dengan meningkatnya atau bertambahnya ketrampilan sosial 
yang dimiliki diharapkan anak mampu menunjukkan sikap prososial sehingga perilaku negatifistik yang menjadi karakteristik $O D D$ akan menurun.

Menurut Gresham (1998), (dalam Jones, 2004:291) social skill merupakan suatu kemampuan belajar menerima perilaku sosial yang menekankan pada kemampuan individu dalam mengintepretasi perilaku orang lain secara efektif dan menghindari suatu perilaku sosial yang kurang diterima orang lain. Gresham (1998) membagai 3 kategori defisit keterampilan sosial:

1. Social skill acquisition deficits yaitu tidak adanya pengetahuan mengenai bagaimana menghasilkan suatu sikap yang sesuai dengan sosial atau kegagalan dalam membedakan kapan seharusnya menghasilkan perilaku sosial yang tepat.

2. Social performance deficits yaitu adanya kemampuan keterampilan sosial dalam pengetahuannya, namun gagal dalam menghasilkan suatu perilaku yang dapat diterima sosial dalam situasi-situasi tertentu.

3. Fluency deficits yaitu adanya kegagalan menunjukkan model perilaku, kurang menampilkan dan mempraktekkan perilaku, rendahnya rata-rata atau kurangnya pemberian reinforcement dari perilaku yang ditunjukkan.

\section{Social Skill Training sebagai metode: Multi-modal-Pendekatan yang terintegrasi}

Terdapat keunggulan dalam menggunakan suatu pendekatan multi-modal dalam Social Skill Ttraining (SST) yaitu dengan menggunakan prinsip yang diantaranya mengandung prinsip-prinsip modelling, reinforcement, dan social problem solving (Bellmann, Pfingsten, dkk dalam Spence, 2003:89).

Program-program multimodal oleh Spense ini efektif dalam meningkatkan ketrampilan sosial yang spesifik pada anak dengan masalah emosional, masalah perilaku dan masalah perkembangan (Spence, 2003:89). Rancangan program yang ada bertujuan menghasilkan ketrampilan sosial yang tepat muncul dalam suatu situasi sosial tertentu. Tentunya akan ada perbedaan rancangan yang diberikan untuk anak dan dewasa, dan tergantung pada kebutuhan ketrampilan sosial yang hendak ditingkatkan. SST pada anak biasanya akan terdiri dari 8 sampai dengan 12 pertemuan. Dalam rancangan kegiatan SST akan meliputi komponen (Spence, 
2003:90), yaitu: 1). Behavioral social skill training yaitu dengan meliputi adanya instruksi, materi diskusi, reinforcement yang digunakan untuk meningkatkan respon perilaku yang tepat. Keterampilan yang dimaksud merupakan keterampilan dasar yang arus dimiliki diantaranya; ketepatan kontak mata, ekspresi muka, nada suara, dll. Dan perlu adanya suatu demonstrasi berupa kegiatan roleplay, diskusi kelompok, dan feedback dari anggota lainnya. 2). Social perception skill training yaitu dimana pada komponen berhubungan dengan perlunya memperlajari cara mengidentifikasi; emosi dan perasaan, emosi dan perasaan dari sudut pandang orang lain, karakteristik aturan sosial yang ada dalam situasi-situasi sosial tertentu, dll. Keakuratan dalam mengintepreasi masalah sosial akan mempengaruhi anak dalam melakukan penyesuaian dan menampilkan perilaku sosial yang tepat. 3). Interpesonal problem solving skill training- yaitu komponen yang mengandung keterampilan untuk melakukan pemecahan masalah. Anak akan mendapatkan pengetahuan dalam mengidentifkasi, mencari alternatif perilaku, mempredikasi konsekuensi, dan akhirnya memilih dan memutuskan perilaku yang tepat dalam situasi tertentu. 4). Self instructional and self-regulation methods yaitu komponen yang meliputi suatu penggunaan internal dialog atau self talk yang akan membantu proses kognitif anak dan munculnya perilaku nyata. Terapis dan membantunya dengan mencatat tahap-tahap dalam suatu keterampilan tertentu yang harus dicapai. Sehingga anak dapat mengikuti tahap-tahap yang telah dipaparkan. Anak akan semakin mudah menyerap materi yang diberikan dan melakukan pengendapan memori atau secara umum terkait pada proses kognitif dari anak tersebut.

\section{Social Skill Training sebagai Intervensi pada Oppositional Deviant Disorder (ODD)}

Menurut Kendal (2003) dengan adanya sikap menentang berarti terdapat suatu permasalahan dengan social skill pada individu tersebut (kendal dalam Hersen, 2006). Kemampuan yang diharapkan bagi anak dengan sikap menentang adalah memiliki toleransi, adaptasi dan kemampuan pemecahan masalah (Greene \& Ablon, 2005 greence \& Doyle, 1999, dalam Hersen, 2006). Karena kemampuan yang berhubungan dengan kapasitas anak dalam menjalin hubungan dalam suatu 
perubahan lingkungan agar memiliki standar dalam diri mereka mengenai perilaku yang tepat (Hersen, 2006).

Anak dengan $O D D$ memiliki kegagalan dalam melakukan kategori strategi perilaku, dan kekuatan dalam merespon secara verbal yang seharusnya diarahkan pada ketepatan dalam perilaku selanjutnya. Anak memiliki keterbatasan dalam mengkomunikasikan perasaannya dan kebutuhannya sehingga interaksi yang nampak menjadi sulit, serta adanya kesulitan dalam pemecahan masalah, sehingga akan nampak ketika anak tersebut harus memutuskan situasi mana untuk memunculkan perilaku yang tepat (Hersen, 2006).

Sehingga dalam penanganan anak dengan $O D D$ ini perlu mendapatkan suatu intervensi yang mampu memberikan model perilaku prososial agar perilaku negativistik yang ada menjadi berkurang. SST yang merupakan suatu intervensi dengan pendekatan khusus yang memiliki tujuan untuk mengembangakan peningkatan suatu perilaku prososial tersebut akan memberikan suatu pengenalan keterampilan sosial yang mana kurang dimiliki oleh anak dengan ODD. SST akan memberikan model dengan materi terkait dengan pola komunikasi dari level yang paling kecil sampai kompleks, strategi pemecahan dan pengambilan keputusan, dsb. Harapannya bahwa anak dengan $O D D$ dapat menggeneralisir perilaku secara lebih luas dalam kehidupan sehari-hari karena telah diperolehnya pengetahuan mengenai keterampilan sosial yang bersifat positif yang dapat digunakan dalam berinteraksi di lingkungan.

Setiap penyusunan rancangan progam intervensi SST perlu diawali dengan sederetan langkah (Roberts, 2010) yang harus ditempuh guna mengetahui keterampilan sosial apa saja secara rinci yang perlu diperoleh sesuai kebutuhan anak $O D D$ tersebut.

\section{Penutup}

Anak merupakan pilar bangsa. Tidak dipungkiri bahwa kemajuan era globalisasi sangat berpengaruh kepada perkembangan psikologis dan perilaku anak seperti pada kasus-kasus yang sedang marak terjadi berkaitan dengan kenakalan, 
bullying, dsb. Sehingga dibutuhkan peran serta dari orang tua, keluarga, sekolah, masyarakat luas untuk mendukung pencapai perilaku prososial pada anak. Selain itu diharapkan pada profesional psikologi khususnya lebih mengasah kemampuannya dalam upaya penanganan kasus-kasus gangguan perilaku anak termasuk gangguan perilaku menentang. Profesional psikolog juga diharapkan lebih mengupayakan program-program preventif yang bertujuan memberikan pengetahuan dan pelatihan sebelum meningkatkan kasus gangguan perilaku pada anak dimasa mendatang. Merupakan tanggung jawab kita bersama untuk membangun bangsa ini melalui sumbangsih karya yang dapat bermanfaat bagi sesama. Masyarakat dapat menjadi kontrol untuk menekan terjadinya permasalahan perilaku pada generasi kita. Tentunya dengan masyarakat yang sehat secara psikologis akan menjadikan bangsa ini menjadi bangsa yang kuat. 


\section{Daftar Pustaka}

Chen, Kaili) (2006)) Social Skill Intervention fo Students with Emotional/Behavior isorder: A Literature Review from the American Perspective) Academic Journals: Educational Research and Reviews, 1 (3)) Hal) 143-149)

Diagnostic and and Statistical Manual of Mental Disorder) Fourth Edition) Text Revision) (2000)) USA)

Hersen, Michel), \& Jay C) Thomas) (2006)) Comprenhensive handbook of Personality and pychopatology) USA: John Wiley \& Sons, Inc)

Jones, Vern), Elizabeth Dohrn), Cory Dunn) (2004)) Creating Effective Programs for Students with Emotional and Behavior Disorder: Interdiciplinaru Approaches for Adding Meaning and Hope to Behavior Change Interventions) USA: Pearson Education)

Mash, Eric J) Wolfe, David A) (1999)) Abnormal Child Psychology) USA: Wadsworth)

Roberts, Clare) (2010)) Mental Health Promotion in Children: Social Life Skill) Perth: Curtin University of Technology)

Segrin, Chris), Melissa Taylor) (2007)) Positive Interpersonal Relations Mediate the Association Between Social Skill and Psychological Well-Being) Journal of Personality and Individual Differences, 43) Hal) 637-646)

Spence, Susah H) (2003)) Social Skill Training with Children and Young People: Theory, Evidence and Practice) Journal Child and Adolescent Mental Health, 8 No) 2) Hal) 84-96)

Sumiati, Neneng Tati) (2006)) Gangguan Sikap Menentang (Membangkang) pada Anak) Jurnal Tazkiya, 6, No) 1) Hal) 44-52) 